\title{
Cytoplasmic Estrogen Receptors of Rat Mammary Glands during Pregnancy and Puerperium
}

\author{
Hiroshi Hoshiai, Katsuyuki Takahashi, Nobuyuki \\ Furuhashi, Yuichi Wada, Shigeki Uehara and Masakuni \\ SUZUKI \\ Department of Obstetrics and Gynecology, Tohoku University \\ School of Medicine, Sendai 980
}

\begin{abstract}
Hoshiat, H., Takahashi, K., Furuhashi, N., Wada, Y., Uehara, S. and SuzukI, M. Cytoplasmic Estrogen Receptors of Rat Mammary Glands during Pregnancy and Puerperium. Tohoku J. exp. Med., 1982, 136 (2), 195-202 The variation of cytoplasmic estrogen receptor in the mammary gland during pregnancy and puerperium was studied to determine the role of estrogens in the mechanism of lactation. Cytosol estrogen receptors from rat mammary glands were incubated with ${ }^{3} \mathrm{H}$-estradiol, and the free estradiol was removed using dextran-coated charcoal. The maximum number of binding sites in the cytosol was estimated from saturation curves and Scatchard analysis. During pregnancy the number of binding sites was relatively low (2.5 to 3.8 pmoles per $\mathrm{mg}$ protein), but increased after delivery to 7.8 pmoles per $\mathrm{mg}$ protein. The number of estrogen binding sites in the mammary glands of lactating rats five days after delivery was at the same level as on the day of delivery. However, at ten days after delivery the number of binding sites increased markedly to 58.9 pmoles per mg protein. The number of estrogen-binding sites in the mammary glands of lactating rats was decreased by castration and by the injection of testosterone or 2-bromoergocriptine. There appeared no competition by testosterone, progesterone or cortisol with estrogen receptors in the mammary gland. - estrogen receptor; mamma; pregnancy; puerperium
\end{abstract}

Several hormones, including estrogen and prolactin, have been reported to regulate the mechanism of lactation, primarily by influencing the production of milk (Hoshiai et al. 1977). It is not yet clear, however, whether these hormones act directly on respective hormone receptors in the mammary gland as a target organ or they act indirectly by a feed-back mechanism upon the mammary gland by changing the concentration in the blood of other hormones receptors for which are present in the mammary gland. The concept of hormone receptors has been established by Jensen and Jacobson (1962) and by Toft and Gorski (1966). Estrogen receptors in the uterus and receptors for other hormones in other target tissues have been demonstrated (Oka et al. 1977). The mammary gland was shown to have receptors for lactogenic hormones such as prolactin, growth hormone and placental lactogen, which participate in regulating the mechanism of milk secretion (Frantz et al. 1974; Holcomb et al. 1976; Djiane et al. 1977). In addition,

Received for publication, May 12, 1981. 
estrogen receptors (Puca and Bresciani 1969; Shyamala and Nandi 1972; Hsueh et al. 1973) and receptors for glucocorticoids (Turnell et al. 1974) have been demonstrated in the mammary gland. The possible presence of a receptor for oxytocin in the mammary gland was indicated by the experiments of Soloff et al. (1972).

The number of binding sites for given hormone may vary with the stage of lactation (Shyamala and Nandi 1972; Hsueh et al. 1973; Djiane et al. 1977). To date, however, little attention has been paid to studies of factors which may alter the number of estrogen binding sites in the mammary gland during different stages of pregnancy and lactation. The present experiments were undertaken to measure the variation in the number of cytoplasmic binding sites for estrogen in the mammary gland during pregnancy and lactation. The effects of the duration of pregnancy, the length of time of breast feeding, and the administration of other hormones on estrogen receptors were studied. Experiments were made to determine whether or not there was an antagonism between estrogen and each of the several steroid hormones which have been reported to participate in regulating milk secretion and in the relationship between the concentration of prolactin in the blood and the number of cytoplasmic estrogen binding sites.

\section{Materials and Methods}

Female Wistar strain rats were divided into groups of four or five and used in the experiments. The day when spermatozoa were present in the vagina after copulation was considered as day zero in expressing the time of pregnancy. Tritium labeled 6,7${ }^{3} \mathrm{H}$-estradiol-17 $\beta$ (60 Ci per mmole) was obtained from the New England Nuclear Corporation. Unlabeled estradiol, progesterone, testosterone and cortisol were supplied by Teikoku Hormone Manufacturing Company (Japan). Just befor use, the steroids were dissolved in the ethanol and diluted to the appropriate concentration with $0.01 \mathrm{M}$ tris$\mathrm{HCl}$ buffer, $\mathrm{pH}$ 7.4, containing 1.5 mM EDTA. 2-Bromoergocriptine (CB-154) was supplied by Sandoz Company (Switzerland).

Dxtran-coated charcoal (DCC) was prepared by the method of Korenman (1970) from dextran-T70 supplied by Daigo Nutrition Company (Japan) and charcoal produced by Merck Company (Germany). Dextran-T70 0.05\% and charcoal $0.5 \%$ were suspended in $0.01 \mathrm{M}$ tris $\mathrm{HCl}$ buffer, $\mathrm{pH} 8$ and stored at $4^{\circ} \mathrm{C}$ until used.

Rats were sacrificed, blood samples were collected, and mammary glands were harvested. The glands were washed in buffer in an iced water bath. Glands were minced finely and pressed to remove any milk present. After washing, the mammary tissue was homogenized in five volumes of buffer and centrifuged at $1000 \times \mathrm{g}$ for $15 \mathrm{~min}$ in the cold. The pellet was discarded and the upper layer of fat was removed. The remaining supernatant fraction was transferred to tubes in a Hitachi RP5-2 rotor and centrifuged at $105,000 \times \mathrm{g}$ for $90 \mathrm{~min}$ in the cold. The resulting supernatant cytosol fraction was stored at $-80^{\circ} \mathrm{C}$ until used. The amount of protein present was estimated by the biuret method (Kingsley 1939).

Cytosol receptor assay. To $0.2 \mathrm{ml}$ of the cytosol supernatant fraction was added $0.1 \mathrm{ml}$ of buffer or of unlabeled hormone at a concentration of $100 \mathrm{nM}$. The mixture was preincubated at $4^{\circ} \mathrm{C}$ for $30 \mathrm{~min}$ with shaking. Then, one of four or five concentrations of labeled estradiol, ranging from 0.044 to $1.2 \mathrm{nM}$ per tube, was added to the mixture and the mixture was incubated at $4^{\circ} \mathrm{C}$ for $60 \mathrm{~min}$ with shaking. Two $\mathrm{ml}$ of $\mathrm{DCC}$ was added and the mixture was incubated for additional $30 \mathrm{~min}$ with shaking in the cold. The mixture was centrifuged at $800 \times \mathrm{g}$ for $15 \mathrm{~min}$ in the cold and $10 \mathrm{ml}$ of Bray's scintillation fluid was added to $0.5 \mathrm{ml}$ of the resulting supernatant. The radioactivity was measured with an Aloka liquid scintillation counter. The counts per min obtained when the assay 
was carried out with the addition of buffer alone during preincubation was called the total binding. The counts per min cbtained when the assay was performed in the presence of $100 \mathrm{nM}$ of unlabeled estradiol was called the nonspecific binding. The difference between the two was regarded as specific binding (Rodbard and Frazier 1975). A dose-response curve was prepared by plotting the specific binding against the amount of ${ }^{3} \mathrm{H}$-estradiol added. The results were plotted by the method of Scatchard (1949) to calculate the number of binding sites and the dissociation constant $K_{d}$.

\section{Results}

Changes in cytoplasmic estrogen receptors of the mammary gland during pregnancy and nursing

Groups of rats were studied at 5 or 20 days of pregnancy, on the day of parturition, and at 5 or 10 days of nursing puerperium. There was no significant change in the dissociation constant of estrogen receptor over this period, averaging $2.5 \times 10^{-10} \mathrm{M}$. The number of estrogen binding sites in the mammary gland was relatively small during pregnancy, ranging from 3.0 to 3.8 pmoles per mg protein on days 10 and 20 of pregnancy, respectively (Fig. 1). On the day of parturition, the number of binding sites in the mammary gland doubled to 7.6 pmoles per $\mathrm{mg}$ protein. This difference was significant $(p<0.05)$. On day 5 of puerperium and nursing, the number of binding sites remained at 8.0 pmoles per $\mathrm{mg}$ protein, but on the day 10 of puerperium and nursing, the number of binding sites increased some sevenfold to 58.9 pmoles per mg protein $(p<0.01)$.

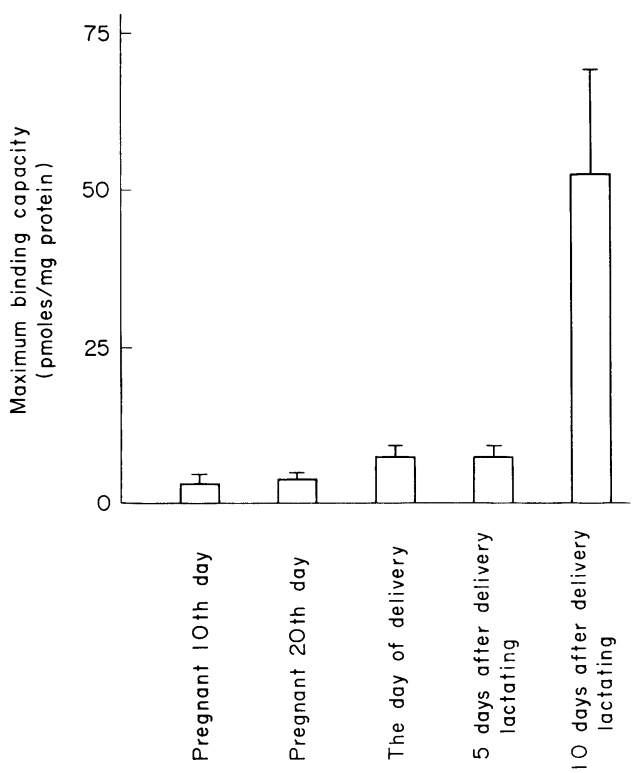

Fig. 1

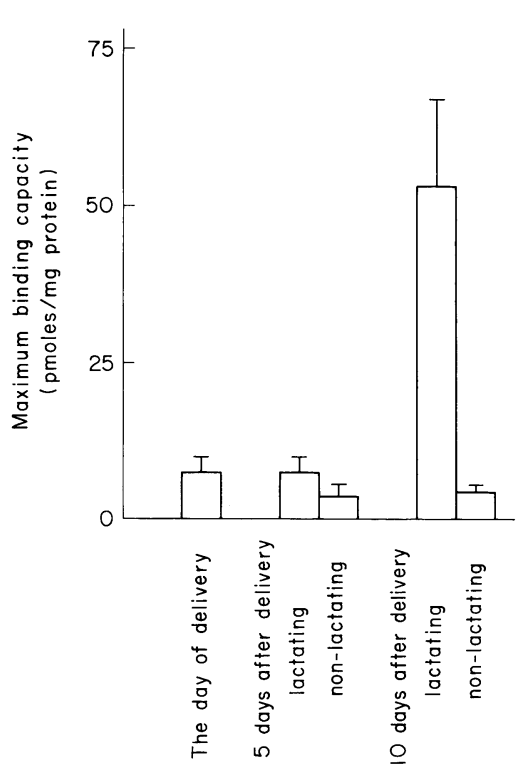

Fig. 2

Fig. 1. The number of estrogen binding sites in the mammary glands of pregnant and lactating rats.

Fig. 2. The number of estrogen binding sites in the mammary glands of lactating and nonlactating rats. 
Number of estrogen binding sites in the mammary glands of lactating and non-lactating rats

In one group of rats, the litters were separated from the mother on the day of parturition. The non-lactating rats were divided into two groups which were examined on days 5 and 10 of puerperium, respectively. The cytosol fractions of the mammary glands were prepared as described earlier, and the number of binding sites and the dissociation constants were measured. The dissociation constants of the estrogen receptors were $2.8 \times 10^{-10} \mathrm{M}$ on day 5 and $3.2 \times 10^{-10} \mathrm{M}$ on day 10 of the puerperium of non-lactating rats. These results were not different from the dissociation constants in the lactating rats. The number of binding sites was 3.6 pmoles per mg protein on day 5 and 3.8 pmoles per $\mathrm{mg}$ protein on day 10 of puerperium in the non-lactating rats (Fig. 2). The number of binding sites was significantly less on both days 5 and 10 in the mammary glands of non-lactating rats than those in the mammary glands of lactating rats. There was no difference between the number of estrogen binding sites in the mammary glands of nonlactating rats on days 5 and 10 .

Effects of the administration of estradiol, testosterone, 2-bromoergocriptine, and of castration on cytoplasmic estrogen-binding sites in the mammary gland during lactation

One group of rats was allowed to nurse the litters after parturition up to 10 days and given $1 \mathrm{mg}$ of estradiol benzoate on the day of parturition and on day 5 of the puerperium. Another group of rats was castrated on the day of parturition, and the third group was injected with $1 \mathrm{mg}$ of testosterone propionate on the day of parturition and on day 5 of puerperium. The fourth group of rats was given 0.6 $\mathrm{mg}$ of 2-bromoergocriptine on the day of parturition and on day 5 of puerperium.

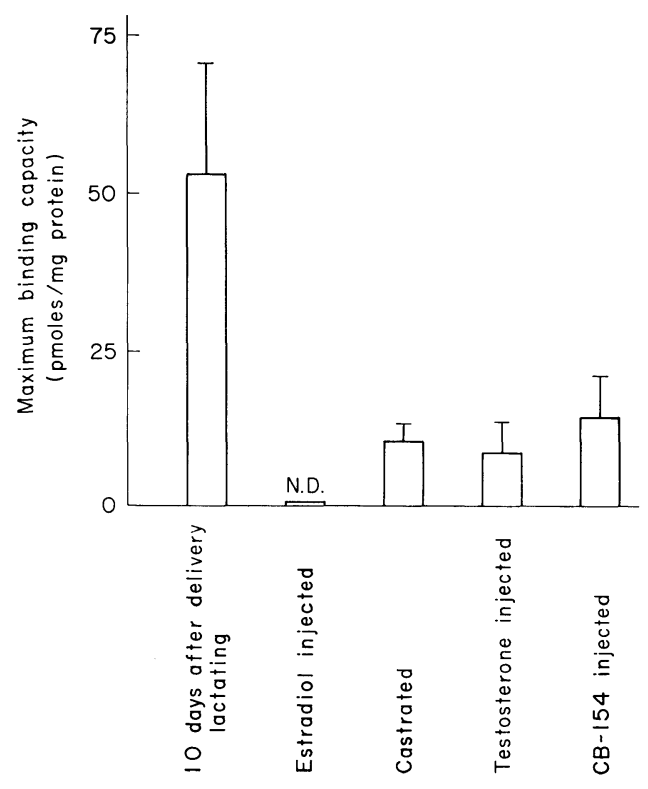

Fig. 3. Effects of estradiol, castration, testosterone and 2-bromoergocriptine (CB-154) on the number of estrogen binding sites in the mammary glands of lactating rats. 
In the cytosol fraction of the mammary glands of rats given estradiol, the number of estrogen binding sites was too small to estimate. The number of estrogen receptors was 10.0 pmoles per mg protein in the mammary glands of the castrated group, 9.3 in the group given testosterone, and 10.4 in the group treated with 2-bromoergocriptine (Fig. 3). Thus, all three treatments reduced the number of estrogen binding sites in the mammary gland as compared with the value of 58.9 pmoles per $\mathrm{mg}$ protein in the untreated lactating rats. However, the number of estrogen binding sites in the mammary glands of all three groups was larger than that in the mammary glands of the non-lactating group, 3.9 pmoles per mg protein.

Effects of testosterone, progesterone and cortisol on the binding of estradiol to the cytoplasmic estrogen receptor of the mammary gland

In further experiments, $100 \mathrm{nM}$ testosterone, progesterone or cortisol was added to the cytoplasmic estrogen receptors during the preincubation period along with aliquots of the cytoplasmic estrogen receptors to which unlabeled estradiol was added or another group which contained no added hormone. Neither testosterone nor progesterone had any effect on the total binding of ${ }^{3} \mathrm{H}$-estradiol (Fig. 4), but when cortisol was added during the preincubation the binding of estradiol was reduced (Fig. 4c). The effects of added cortisol on estrogen binding were expressed by both Linewever-Burk and Scatchard plots, but neither revealed antagonism at the receptor site.

\section{Discussion}

Many studies of estrogen receptors in a variety of tissues agree in asserting that the dissociation constant of the receptor is at the level of $10^{-9}$ to $10^{-10} \mathrm{M}$ with a very high specificity of binding. The number of binding sites ranges from $10^{-12}$ to $10^{-14} \mathrm{M}$ per $\mathrm{mg}$ protein in different tissues (Kato 1974; Reichman and Villee 1978). The cytoplasmic estrogen receptor of the mammary gland has a dissociation constant at the level of $10^{-10} \mathrm{M}$ and showed the same binding specificity as that of other estrogen target tissues (Puca and Bresciani 1969; Shyamala and Nandi 1972; Hsueh et al. 1973). The binding reaction between estrogen and the cytoplasmic receptor sites can be observed in the uterus within $15 \mathrm{~min}$ after the beginning of the reaction and reaches a plateau in 45 to $60 \mathrm{~min}$ (Hoshiai 1979). There was little or no change in the number of binding sites in the mammary gland during pregnancy, but a sharp increase on the day of parturition and a very large further increase on the 10th day of puerperium. This increase did not occur in the non-lactating rats during puerperium. Experiments comparable to the present one have been carried out by Hsueh et al. (1973) who also reported increases in both cytoplasmic and nuclear estrogen receptors on the 10th and 20th days of puerperium. Both results demonstrate an increase in binding sites in the mammary gland after parturition. In rats and other mammals there is a correlation between the amount of milk secreted and the gain in body weight of the litter. The gain in body weight of the litter is greater at 10 days of the puerperium than just after parturition and 

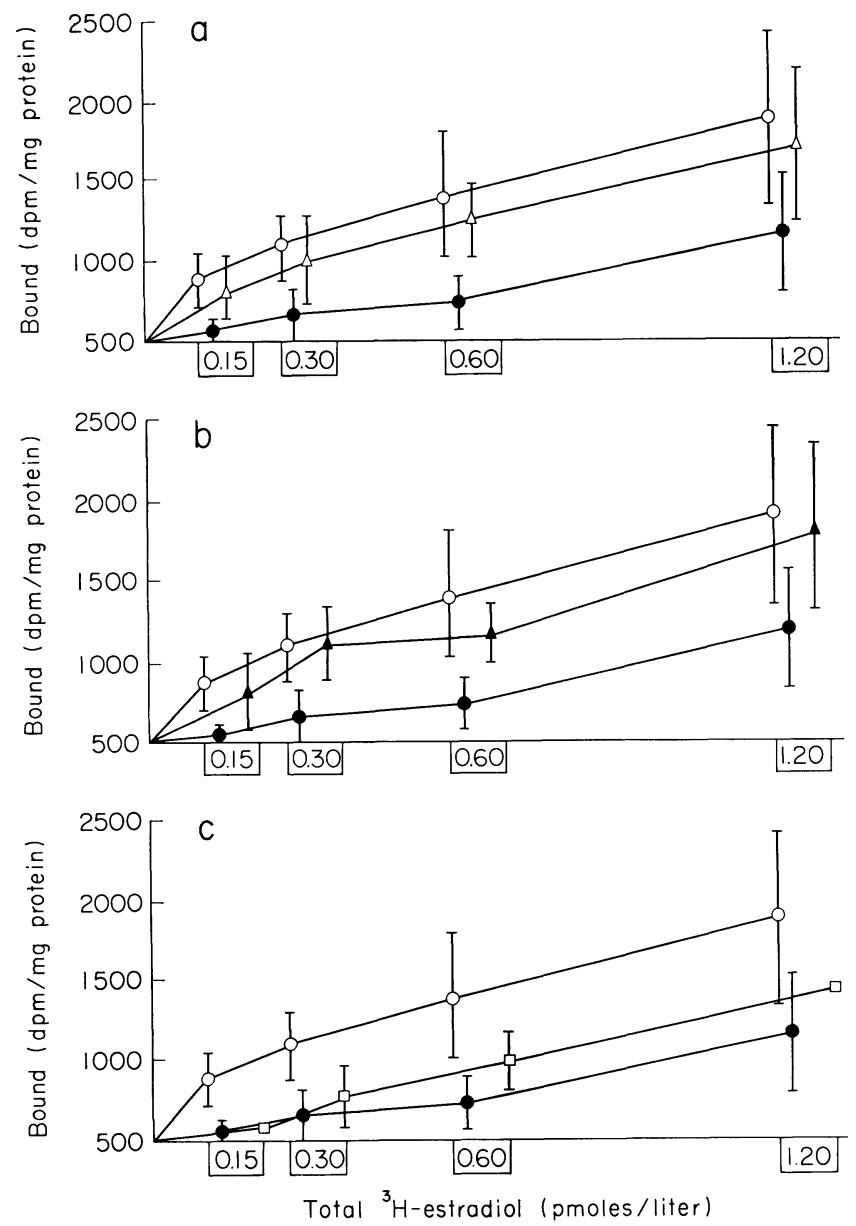

Fig. 4. Effects of testosterone, progesterone and cortisol added in vitro on the ${ }^{3} \mathrm{H}$ estradiol binding of nursing rat's mammary gland on the 5th puerperal day. Incubated mixtures after preincubation with no addition of hormone $(0-0)$ or with addition of estradiol $(\bullet-\bullet)$, testosterone $(\Delta-\Delta)$, progesterone $(\boldsymbol{\Delta}-\mathbf{\Delta})$, or cortisol $(\square-\square)$.

it is assumed that the function of the mammary gland in secreting milk is also greater on the 10th day of the puerperium than earlier. These results suggest that the number of estrogen binding sites increases with the increased milk secretion. The administration of estrogen, however, has an inhibitory effect upon milk secretion. The difference in the number of estrogen binding sites in the mammary glands of lactating and non-lactating rats is of interest for the number of binding sites in non-lactating rats was very much smaller than those in the mammary glands of lactating rats. The number of estrogen binding sites in non-lactating rats was similar to that during pregnancy or in rats in which no milk secretion was taking place. Other experiments tested the possibility that some endocrine factor other than lactation itself might change the number of estrogen binding sites. Gorski 
et al. (1970) reported that the administration of $1 \mu \mathrm{g}$ of estradiol reduced the number of estrogen cytoplasmic receptors in the uterus to $50 \%$ and that $16 \mathrm{hr}$ was required for the amount of receptor to return to the initial level. The large dose of estradiol benzoate used in the present investigations $(1 \mathrm{mg})$ led to the virtual disappearance of estrogen receptors; the number remaining was so small that it could not be estimated.

Two groups of authors have reported on the effects of castration on estrogen receptors. Martin et al. (1975) reported that the cytoplasmic estrogen receptor of the uterus was increased by ovariectomy in the rabbit, and Hsueh et al. (1973) reported that castration had no effect on cytoplasmic estrogen receptors in the mammary gland during the puerperium. In these experiments castration had no effect on the number of estrogen binding sites per mg protein in the mammary gland, but the size of the mammary gland in the castrated rats was only about one-fifth that in the intact rat lactating since parturition. The number of estrogen receptors in the mammary gland of the lactating rat was two or three times greater than that in a non-lactating rat.

The administration of 2-bromoergocriptine to mammary tumors in rats reduced the number of cytoplasmic estrogen receptors (Vignon and Rochefort 1976). A similar result was obtained in the present experiments using normal mammary tissues. It is not possible to determine whether the reduced number of estrogen receptors was brought about by the same mechanism in the two types of experiments. Testosterone, as well as estrogens, inhibits milk secretion by the mammary gland. In these experiments testosterone administered in vivo reduced the number of estrogen binding sites in the mammary gland, but in in vitro experiments unlabeled testosterone did not compete with labeled estradiol for binding to the receptor. This suggests that testosterone inhibits milk secretion indirectly by the number of estrogen binding sites in the mammary gland.

\section{Acknowledgments}

We are grateful to Dr. Claude A. Villee, Andelot Professor of Biological Chemistry, Harvard Medical School, for reading the manuscript. We also express our thanks to Ms. Kathleen Callinan for typing the manuscript and to Ms. Yoko Hirose, Mrs. Syoko Konno and Ms. Saeko Suzuki for their assistance.

\section{References}

1) Djiane, J., Durand, P. \& Kelly, P.A. (1977) Evolution of prolactin receptors in rabbit mammary gland during pregnancy and lactation. Endocrinology, 100, 13481356.

2) Frantz, W.L., MacIndoe, J.H. \& Turkington, R.W. (1974) Prolactin receptors: Characteristic of the particulate fraction binding activity. J. Endocr., 60, 485-497.

3) Gorski, J., Sarff, M. \& Clark, J. (1970) The regulation of uterine concentration of estrogen binding protein. Advanc. Biosci. 7, 5 .

4) Holcomb, H.I., Costlow, M.E., Buschow, R.A. \& McGuire, W.L. (1976) Prolactin binding in rat mammary gland during pregnancy and lactation. Biochem. biophys. Acta, 428, 104-112.

5) Hoshiai, H., Takahashi, K., Wada, Y., Sakurada, N. \& Suzuki, M. (1977) The 
mechanism of lactation and hormone receptor of mammary gland. Obstet. Gynecol. Japan, 44, 35-45. (Japanese)

6) Hsueh, A.J.W., Peck, E.J., Jr. \& Clark, J.H. (1973) Oestrogen receptors in the mammary gland of the lactating rat. J. Endocr., 58, 503-511.

7) Jensen, E.V. \& Jacobson, H.I. (1962) Basic guides to the mechanism of estrogen action. Rec. Prog. Horm. Res., 18, 387-414.

8) Kato, J. (1974) Biochemistry of intracellular hormone-estrogen. Sogo-Rinsyo, 23, 1246-1255. (Japanese)

9) Kingsley, G.R. (1939) The determination of serum total protein, albumin and globulin by the Biuret reaction. J. biol. Chem., 131, 197-200.

10) Korenman, S.G. (1970) Relation between estrogen inhibitory activity and binding to cytosol of rabbit and human uterus. Endocrinology, 87, 1119-1123.

11) Martin, J.E., Philpott, J., Chatkoff, M., Young, R. \& Pauerstein, C.J. (1975) Effect of progesterone on estrogen receptors in the rabbit uterus. Amer. J. Obstet. Gynecol., 121, 181-186.

12) Oka, H., Osawa, N. \& Kato, J. (1977) Hormone Receptor, Chugai-Igakusya, Tokyo, Japan. (Japanese)

13) Puca, G.A. \& Bresciani, F. (1969) Interactions of 6,7-3 H-17 $\beta$-estradiol with mammary gland and other organs of the $\mathrm{C} 3 \mathrm{H}$ mouse in vivo. Endocrinology, 85, 1-10.

14) Reichman, M.E. \& Villee, C.A. (1978) Estradiol binding by rat thymus cytosol. $J$. Steroid Biochem., 9, 637-641.

15) Rodbard, D. \& Frazier, G.R. (1975) Statistical analysis of radioligand assay data. In: Methods in Enzymology, Vol. 37B, edited by B.W. O'Malley \& J.G. Hardman, Academic Press, New York, p. 3.

16) Scatchard, G. (1949) The attractions of proteins for small molecules and ions. Ann. N.Y. Acad. Sci., 5, 660-672.

17) Shyamala, G. \& Nandi, S. (1972) Interactions of $6,7-{ }^{3} \mathrm{H}-17 \beta$-estradiol with the mouse lactating mammary tissue in vivo and in vitro. Endocrinology, 91, 861-867.

18) Soloff, M.S., Swartz, T.L. \& Saffran, M. (1972) Specific uptake of radioactivity from ${ }^{3} \mathrm{H}$-oxytocin by surviving segment of mammary gland. Endocrinology, 91, 213216.

19) Toft, D. \& Gorski, J. (1966) A receptor molecule for estrogens: Isolation from the rat uterus and preliminary characterization. Proc. nat. Acad. Sci. USA, 55, 1574-1581.

20) Turnell, R.W., Beers, P.C. \& Wittliff, J.L. (1974) Glucocorticoid binding macromolecules in the lactating mammary gland of the mole. Endocrinology, 95, 17701773.

21) Vignon, F. \& Rochefort, H. (1976) Regulation of estrogen receptors in ovariandependent rat mammary tumors. 1. Effect of castration and prolactin. Endocrinology, 98, 722-729. 